\title{
AN EMBLEMATIC PORTRAIT?
}

We proceed to consider the last of Rembrandt's seven sitters.

\section{FRANS VAN LOENEN}

What place does Frans van Loenen have in this historically-composed groupportrait? Van Loenen is the hatted figure at the apex of the outer triangle of surgeons (PI. 1). He looks straight at the viewer, and consciously directs our attention by pointing his index-finger at the scene below him. These two actions, of face and hand, are the characteristic traits of the attributive portrait: van Loenen's whole attitude could not be more unhistorical than it is. ${ }^{106}$ But if van Loenen's attitude is so blatantly unhistorical, there would have been no purpose in Rembrandt's effort to avoid offending against historical rationality in the attitudes of all the other sitters. Must we accept that Rembrandt's picture is, after all, divided by a discrepancy of genre, between the attributive pose of van Loenen and the historical attitudes of the other six sitters? If so, the rest of the scene serves as van Loenen's attribute, and gives him a prominent role which would seem more suitable for the praelector (cf. Pl. 6). The alternative would be to modify our identification of the picture's genre, and there are in fact several weaknesses in that identification which suggest how it might be adapted to accommodate the troublesome figure of van Loenen.

First, although the pose of each sitter (except van Loenen) may be historical, it does not necessarily follow that the ensemble of sitters is also historical, and in fact it is not. In order to illustrate the successive stages of his argument, Dr. Tulp is portrayed as if he were demonstrating them all at the same time. With his right hand he differentiates the two flexor-muscles of the fingers: this is the first stage of the demonstration, in which the physical form of the flexor-mechanism is explained. With his left hand he demonstrates a later stage, the discussion of the use of the mechanism. Finally, his facial expression shows that he is mentally already at the climax of his exposition: the Galenic and Laurentian view of the hand as organ of prehension, instrument of instruments, unique to man, a miracle of design, and a monument of the wisdom and power of the Creator. The surgeons respond to Tulp in correspondingly disparate ways. Slabberaen, on the left, is still at the first, purely perceptual, phase: he gazes with feline detachment at a technical illustration on the hidden recto page of the folio volume. His neighbour de Witt is also still interested in the mere physical details of the musculature, but the eagerness with which he inspects it suggests that its conceptual significance may very soon be dawning on him. Calkoen and Block, who stare at the gesture of Tulp's left hand, have reached the second stage, and Calkoen is well on his way to the third stage, the revelation which has already left Hartmansz. gaping in amazement and Tulp himself entranced. Therefore the picture as a whole does not

\footnotetext{
${ }^{106}$ The hand-gesture is of course the typical action of the saint pointing to his attribute in fifteenth- and sixteenth-century painting. Bosch's St. John the Baptist (Madrid) matches it exactly.
} 


\section{The paradox of Rembrandt's 'Anatomy of Dr. Tulp'}

capture a split second in a historical (albeit fictitious) narrative. ${ }^{107}$ The simultaneous depiction of successive events was, of course, practised by model history-painters such as Leonardo, Raphael, and Titian, but for Rembrandt in the 1630s, the task of the history-painter, as we can deduce it from such paintings as the London Belshazzar's feast (c. 1635) and the Frankfurt Samson (1636), was precisely the opposite: namely, to isolate a single "frozen moment" in a sequence already familiar to the viewer. The Tulp picture, therefore, fails to meet this first criterion of Rembrandtian historicity.

Second, there is the fact that, in a real anatomy, public or private, the first part to be incised was invariably the abdomen. ${ }^{108}$ The limbs were not dissected until the head and trunk had reached a spectacular state of spoliation. In Rembrandt's picture, however, the flexor-mechanism of the hand has already been painstakingly dissected, while the rest of the body is still intact. Even if the painting had been a historical picture unified around a single central action, it could not have carried conviction with contemporaries, since the action, through its defiance of the normal sequence of events, would have been one which they knew could never have occurred. This suggests that Tulp deliberately selected this particular dissection for some conceptual significance which it possessed, and not merely to record the historical fact that he had been praelector anatomiae. What that significance may have been has already been suggested: the concept of the pre-eminence of the hand, as propagated by Galen, Laurentius, and others.

These defects in the "historical" identification of the picture's genre both point towards the same alternative explanation: that Tulp and the surgeons consciously posed in such a way as to illustrate a pre-selected argument. There is other evidence which points in the same direction.

The iconography of Rembrandt's painting must have been the responsibility of Nicolaes Tulp himself. The choice of Tulp's action in the picture, implying as it does a Galenic or Laurentian interpretation of a Vesalian motif, required a knowledge of anatomy-books written in Latin, knowledge which was presumably outside the educational range of both Rembrandt and the surgeons. It is on Tulp's choice for his own attitude in the picture that the attitudes of the surgeons depend, particularly of Calkoen, Block, and Hartmansz.: they could hardly have looked with such great admiration on the anatomical specimens displayed by Dr. Sebastiaen Egbertsz. or Dr. Johan Fonteyn in their comparable' pictures (Pls. 3, 5, 6). Tulp must therefore have determined the attitudes of the surgeons also, and from that point it becomes difficult to define the further limits of his responsibility for the content of Rembrandt's painting. One may therefore compare this picture directed by Nicolaes Tulp (Pl. 1) with another picture for which he had iconographic responsibility: his portrait by Nicolaes Eliasz. or Pickenoy, which is dated 1634 (Pl. 18). Here also Tulp has selected a pose which would illustrate an idea. He looks wistfully at the viewer while he points - again the typical attributive combination - at the melting candle which exemplifies the

\footnotetext{
${ }^{107}$ Cf. Heckscher p. 33.

${ }^{108}$ Heckscher p. 66. A. Laurentius, Historia anatomica, Frankfurt a. M., 1599, I, c. 9, p. 11 “. . . imum ventrem prius seca, mox thoracem, dein caput, tandem artus. Hanc methodum in scholis et sectionibus publicis obseruant anatomici omnes ..."; A. Piccolomini, Anatomicae praelectiones, Rome, 1586, p. 55; etc.
} 


\section{An emblematic portrait?}

motto carved on an ageless marble monument: "In serving others I myself am consumed". If one had to identify the genre of this picture, one would surely call it an emblematic portrait. If Tulp, in 1634, intended that a portrait over which he had complete iconographic control (Pl. 18) should be composed and understood as an emblem, or illustration of a given concept, could he not have intended, in 1632, that a groupportrait (Pl. 1), in whose choice of iconography his taste was probably dominant, should also have emblematic significance?

Our suggestion is that Rembrandt's painting (Pl. 1) may be not a group-portrait composed as a history-picture, but an emblematic group-portrait. The motto, undisclosed as usual in emblematic paintings, would be a summary of the argument being presented by Dr. Tulp: something like EST DEVS IN NOBIS seems called for. ${ }^{109}$ Of course, the "emblem", the dissection of the hand, is not an established one that Tulp could have borrowed from a contemporary emblem-book, as he did with the melting candle in his portrait by Eliasz. (PI. 18). ${ }^{110} \mathrm{It}$ is too specialized for such wide circulation. But it is not an entirely original illustration either, since Tulp derived it and its putative meaning from Vesalius and possibly Fabricius ab Aquapendente (PI. 10; Fig. 4), and it would have been easily understood by anyone who had attended Tulp's public anatomies. In the emblematic scene that emerges, the five surgeons we have considered would be driving home the lesson with the attentive or excited attitudes allotted to them by the iconographic authority, Doctor Tulp. Their individual historical poses can contribute to an emblematic picture, but the emblematic attitude of Frans van Loenen cannot be admitted to a strictly historical picture. ${ }^{111}$ Therefore if the whole painting is an enormous emblem-picture, van Loenen can be accepted into the scheme we have already identified for the other surgeons and the praelector: Tulp impresses the argument on the five lower surgeons; they, by their attitudes, confirm its importance; and van Loenen mediates their joint lesson to the viewer.

This interpretation would explain why van Loenen was originally depicted wearing a hat (PI. 1). Heckscher believed that only the lecturer at an anatomy wore a hat, ${ }^{112}$

\footnotetext{
109 "God is within us": Ovid, Ars. am. III. 549 and Fasti VI. 5, cited by, among others, Laurentius, op. cit., note 108 above, lib. VI, quaestio xxii, p. 242.

${ }^{110}$ Heckscher p. 120. But Tulp's immediate source for the candle-motif has not been traced. Heckscher (p. 177) tentatively suggested P. C. Hooft's Emblemata amatoria, Amsterdam, 1611, p. 35, no. 12 (Heckscher pl. XIV-54): there, however, we find only SERVIENDO CONSUMOR. Perhaps Tulp's source was G. Rollenhagen, Selectorum emblematum centuria secunda, Utrecht, 1613, no. 31 (with the same word INSERVIENDO, not IN SERVIENDO as reported by A. Henkel and A. Schöne, Emblemata, Stuttgart, J. B. Metzler, 1967, col. 1363). However, Frits Graf, 'Aliis inserviendo consumor', Arcadia, 1969,4 : 199-201, shows that the motto existed before this date, though without resolving the question of its origin. For further literature see Peter Hecht, "Candlelight and dirty fingers, or royal virtue in disguise: some thoughts on Weyerman and Godfried Schalcken', Simiolus, 1980, 11: 23-38, pp. 27-28. There may be an unnoticed allusion to this idea in John Donne's poem The canonization, v. 21, "We are tapers too, that at our own cost die."

${ }^{11}$ Admittedly, L. B. Alberti liked to see in historical pictures "someone in the story who tells the spectators what is happening, and ... beckons them with his hand to look ..." (On painting and sculpture, ed. and transl. C. Grayson, London, Phaidon, 1972, pp. 80-83 [De pictura book II]). But many painters have not shared Alberti's preference, and in any case his theoretical idea of a historia is closer to the modern idea of an emblem-picture than to a historical painting by Rembrandt.

112 Heckscher pp. 40, 118, 175, where, however, comparisons with academic practice are beside the point, since anatomies at Amsterdam were civic, not academic, affairs.
} 


\section{The paradox of Rembrandt's 'Anatomy of Dr. Tulp'}

but our sources do not confirm this view. It seems that hats were worn by most if not all members of the audience in an anatomy-theatre, which was after all a cold public place. ${ }^{113}$ If certain group-portraits portray only the praelector as hatted, it must therefore be because the painter wished to single out the most important sitter, the praelector. It would otherwise be even less easy than it is for the viewer to pick him out. ${ }^{114}$ But this pictorial device is introduced only in the group-portraits made in the time of Tulp's two immediate predecessors, Egbertsz. and Fonteyn (Pls. 5, 6), whose iconographic innovations Tulp accepted, as we shall eventually see. ${ }^{115}$ Therefore the fact that both van Loenen and Tulp are hatted suggests that van Loenen also, although a mere surgeon, is raised to a didactic rank in the picture, as though he also were what his colleague Calkoen actually was, Dr. Tulp's assistant. ${ }^{116}$ Van Loenen is presented as unofficial assistant praelector anatomiae whose task in the painting is to pass on Tulp's message to the viewer and to posterity. One can imagine many reasons why this misleading implication should have been resented, and the hat painted out.

The primary case for this argument is its ability to account for the actions of all seven sitters with one interpretation. But there is also the argument that this interpretation is no more than we should already have suspected from the evidence of the culture in which the painting was produced. Leiden and Amsterdam, the two cities in which both Tulp and Rembrandt received their training and made their careers, formed "the undisputed centre of European emblem-literature of the early seventeenth century". ${ }^{117}$ Again, we read that "the visual arts of the first few decades of the seventeenth century display an overwhelming preference for the expression of ideas, for underlining the importance of salvation, and for an intellectual comprehension of the subjects depicted". ${ }^{118}$ This statement too bears out the "emblematic", but not the "historical", interpretation of Rembrandt's picture. Rembrandt's professional interest in emblems is said to have been rather faint, ${ }^{119}$ but Dr. Tulp, humanist and physician, was of exactly the class which did most to foster their cult, and according to our hypothesis it was Dr. Tulp who chose the genre and subject of the picture, while Rembrandt merely executed the commission - with precocious virtuosity and wholehearted understanding of his task. On the evidence adduced so far, then, this task would seem to have been to paint an emblematic portrait of Dr. Tulp and the surgeons teaching and studying anatomy as a revelation of the divine presence in the human body.

${ }^{113}$ See Pls. 8, 15, and 17, and Heckscher p. 25.

114 As noted by W. Weisbach, Rembrandt, Berlin and Leipzig, W. de Gruyter, 1926, p. 303.

115 p. 38 below.

${ }^{116}$ Cf. p. 55 below.

11 'Sibylle Penkert, 'Zur Emblemforschung', in Emblem und Emblematikrezeption, ed. S. Penkert, Darmstadt, Wissenschaftliche Buchgesellschaft, 1978, p. 19.

118 Hessel Miedema, 'Realism and the comic mode: the peasant', Simiolus, 1977, 4: 205-219, p. 219.

119 Heckscher p. 120 . However, Rembrandt's allegorical etchings (B. 109-11) are close to this genre. 